\title{
Developing the Rural Town of Panchor into a Future River-based Tourism Destination: Host community perception
}

\author{
Mazni Saad ${ }^{1}$, Nur Nabilah Abdullah ${ }^{2}$, Siti Nur Hidayah Rosman ${ }^{1}$ \\ 1 Department of Tourism, ${ }^{2}$ Department of English \\ Kulliyyah of Languages and Management, Kulliyyah of Languages and Management, \\ International Islamic University Malaysia, Edu Hub Pagoh, KM1, Jalan Panchor, Pagoh 84600 Muar, Johor, Malaysia \\ maznisaad@iium.edu.my, nnabila@iium.edu.my, cthidayahrosman@gmail.com \\ Tel: 60178787543
}

\begin{abstract}
This paper examines the significance of a rural area, Panchor village town, as a potential nature tourism site in the Muar district of Johor, Malaysia. The objectives of the study were (1) to evaluate local community support and (2) to assess local community involvement. Based on qualitative analysis of an interview and open-ended responses in the questionnaire, three interconnected themes were: (1) community attachment, (2) economic gains and (3) environmental attitude. The findings revealed that river-based tourism development could stimulate the socio-economic status and the sustainability of rural areas. This study also discussed implications and limitations of the research.
\end{abstract}

Keywords: Community Attachment; Economic Gains; Environmental Attitude; River-based Tourism

eISSN: 2398-4287@ 2020. The Authors. Published for AMER ABRA cE-Bsby e-International Publishing House, Ltd., UK. This is an open access article under the CC BYNC-ND license (http://creativecommons.org/licenses/by-nc-nd/4.0/). Peer-review under responsibility of AMER (Association of Malaysian Environment-Behaviour Researchers), ABRA (Association of Behavioural Researchers on Asians) and cE-Bs (Centre for Environment-Behaviour Studies), Faculty of Architecture, Planning \& Surveying, UniversitiTeknologi MARA, Malaysia.

DOI: https://doi.org/10.21834/ebpj.v5i14.2236

\subsection{Introduction}

The state of Johor aims to transform into a high-value regional tourism destination by 2023 (Benjamin, 2018), an aspiration aligned with the Johor Tourism Master Plan 2014-2023. As its goal is to increase tourist arrivals from domestic and foreign countries to Johor, the district of Muar has been intensifying efforts at maximising its tourism potentials with an attractive new tourism product. Muar, an already popular tourist destination, boasts of well-preserved pre-historic buildings, an exciting culture, and delectable cuisine. Muar features its strategic location at the mouth of Muar River in a new river-based tourism development project proposal for the rural town of Panchor. According to Rahman et al. (2020) and Shah (2018), this is potentially the tourism product that could help Muar achieve its tourism development target.

Panchor, the target of a new river-based tourism destination is a rural town strategically located next to Muar River and has Pagoh Education Hub for a neighbour. Presently, the Muar River that flows through Panchor serves as the town's local fisheries and has several restaurants well-known for serving delicious seafood and other local dishes. Most of the tourists are local and come to Panchor for just a day to enjoy the food by the riverside and will usually cruise down to Muar town for more exciting activities such as jet skiing and dragon boating (see Fig. 1). Many tourists opt for river cruises that take them closer to Muar town for a wider range of river activities or even to other bigger towns across the Johor state border. Panchor, however, has to move forward as a tourist destination to attract more high-value tourists to stay for longer visits in the region (Benjamin, 2018). The town has to be revitalised into what it was like in the early 70 s - an administrative centre of the upper Muar river (Zakaria, 2020) with an essential waterway for traders between the West Coast and the Peninsula that was key to the local community's socio-economic status (Samah et al., 2011). Panchor's Muar River must be

eISSN: 2398-4287C 2020. The Authors. Published for AMER ABRA cE-Bsby e-International Publishing House, Ltd., UK. This is an open access article under the CC BYNC-ND license (http://creativecommons.org/licenses/by-nc-nd/4.0/). Peer-review under responsibility of AMER (Association of Malaysian Environment-Behaviour Researchers), ABRA (Association of Behavioural Researchers on Asians) and cE-Bs (Centre for Environment-Behaviour Studies), Faculty of Architecture, Planning \& Surveying, UniversitiTeknologi MARA, Malaysia.

DOI: https://doi.org/10.21834/ebpj.v5i14.2236 
more than the local fisheries for the local community. To do this, it needs to rope in the local community's cooperation and participation in promoting Panchor's local tourism through a successful and sustainable river-based tourism development project.

Tourism today has evolved, and tourists demand more excellent value for their holidays. River tourism destinations have become more popular nowadays, where 21 st-century tourists view their holidays differently. They seem to look for specific forms of tourism, seeking new experiences and adventures as well as gaining higher levels of holiday quality (Trono, 2014). Given these trends, riverbased tourism could offer great potential for conserving and preserving rivers as natural resources as well as revitalising and developing tourist destinations that emphasise sustainable and community-based tourism (Folgado-Fernández, Di-Clemente, Hernández-Mogollón, \& Campón-Cerro, 2019). As shown in Fig. 2, Muar River has the main feature of today's river-based tourism that has a natural setting, where people seek relaxation, leisure, and recreation (Jennings, 2016). Hence, the present study aims to investigate the possibility of a river-based tourism development plan of the Muar River in the rural town of Panchor. More importantly, it sets out to investigate and evaluate the local community's support and involvement in the future river-based tourism development of Panchor's Muar River.

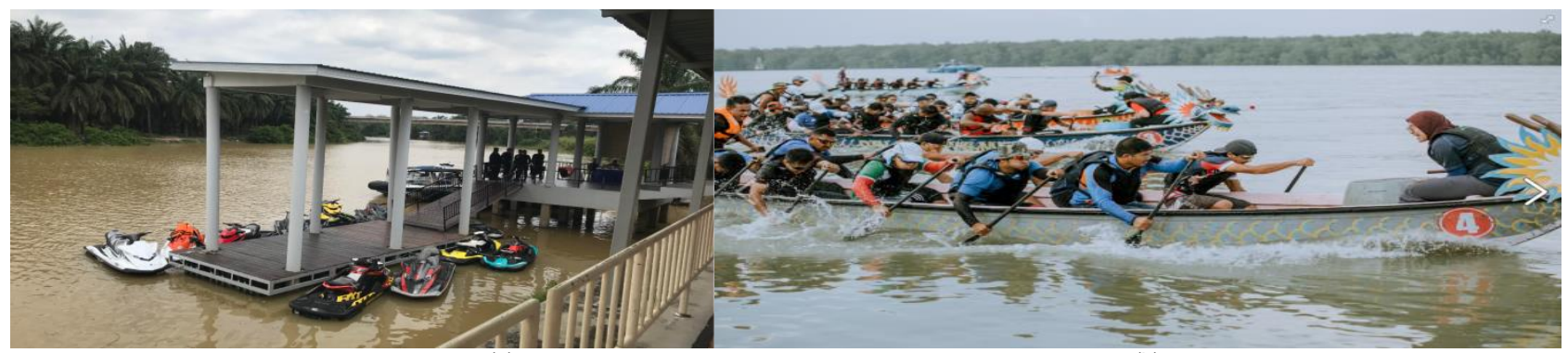

(a)

Fig. 1. (a) Jet Ski; (b) Dragon Boat

(b)

Source: (a) Mazni Saad (2019) (b) Muar International Dragon Boat Race (2019)

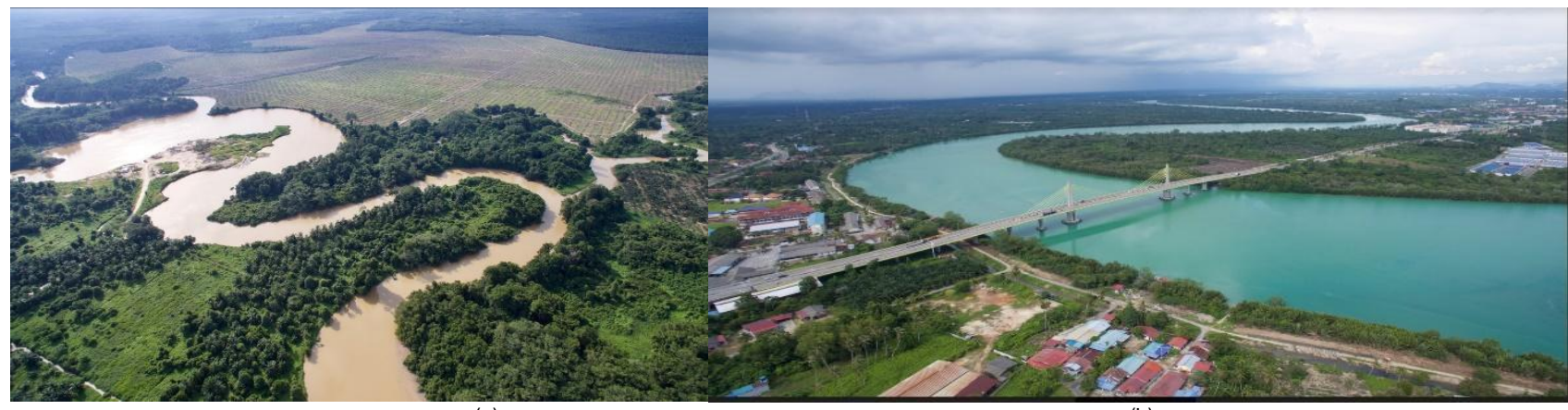

(a)

(b)

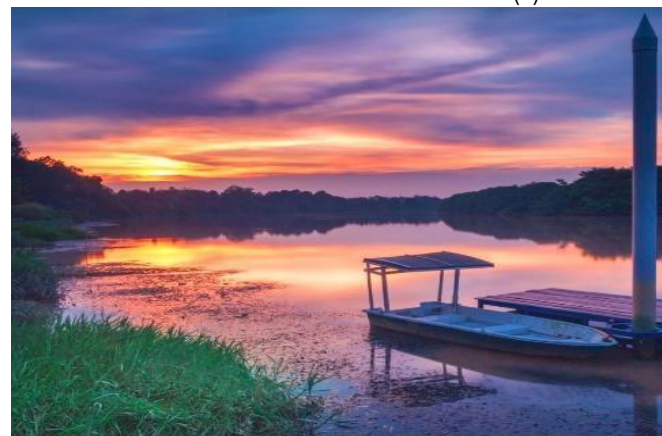

(c)

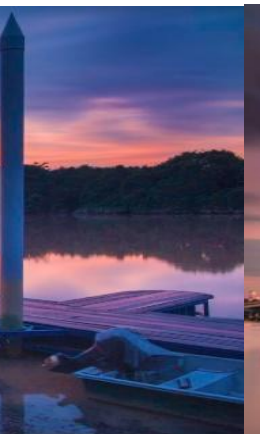

Fig. 2: Muar River

Source: (a) and (b) JackieNg, (c) and (d) Datuk Gan Hong Su (2020)

\subsection{Literature Review}

\section{River-based Tourism}

The natural resources of rivers manifest both natural beauty and usefulness for a vast array of human activities including river-based tourism such as river cruises, fishing, boating, and other forms of tourism activities (Laws \& Sermone, 2009). The Muar River plays a key role in Malaysia's history, culture, and economy. Hence, the Muar district in Johor has made an enormous effort to increase its tourism potential with an attractive new tourism product, such as potential river tourism in the Panchor rural area strategically located next to the Muar River. It is no doubt that the potential river-based tourism may contribute to Johor state's foreign income and the 
Panchor local community's economic status. Nevertheless, issues related to the local community's socio-economic well-being, support and involvement need to be taken into account.

\subsection{Underlying Theory}

Homans' Social Exchange Theory (SET) (Tittenbrun, 2012) is referred to in this study as relevant in inferring the social behaviour of the local community of Panchor as an outcome of an exchange process. The theory focuses on the attitude and perception of the host community (Meimand et al., 2017). The theory also demonstrates that if risks outweigh benefits, the relationship between the host community and the development tourism project will usually be terminated. Residents' belief is crucial as they are likely to be more persuaded to support tourism development when they can gain advantage from tourism without suffering additional costs (Homsud, 2017). A strong and positive perspective is needed to engage the local community into supporting tourism development activities intended for their area. SET underlines many tourism developments studies such as those by Chuang (2010), Ward and Berno (2011), Paraskevaidis and Andriotis (2017), to name a few.

\subsection{Local Community's Support towards Tourism Development}

A local community is a formal tradition-based organization consisting of individuals and households who reside in a particular area (Kariuki, 2013). It refers to people who have also come together to share common resources within the area, thus contributing to a certain extent similar feelings, attitudes, perceptions, and aspirations towards tourism development. While local community's support ensures the sustainability of the commercial, socio-cultural, physiological, politics and economics of the industry (Alonso \& Liu, 2013; Dorcheh, \& Mohamed, 2013), their involvement is vital in influencing the success of further tourism development. Scholars, according to Dorcheh and Mohamed (2013) believe that community perception is an essential area of research in tourism. As past studies (Diedrich \& García-Buades, 2009; Dorcheh \& Mohamed, 2013) have shown that crucial to achieving sustainable tourism development is getting the community members mainly involved in the decision-making process.

\subsection{Local Community's Attachment towards Tourism Development}

Community attachment refers to the feelings, emotions, and sense of belonging that a community feels towards the town (Rasoolimanesh, Jaafar, \& Ahmad, 2017). Past literature measured local community in a variety of ways such as the length of the living or having born or grown up in the community (Brida et al., 2014). Literature shows a mixed result in the study of the relationship between community attachment and resident perception. Meimand et al. (2017) and Rasoolimanesh, Jaafar, and Kock (2015) argue that residents who have secure attachment feelings are more sensitive towards the positive and negative effects of tourism, which affect their support toward tourism development. Morales, Agüera, and López-guzmán (2018) also found a positive influence from the attachment of the community towards support for expansion in tourism development. The study reveals that the local community's support for sustainable tourism development depends on the level of attachment that residents have towards their community.

\subsection{Methodology}

\subsection{Study Area}

Panchor has an approximate surface area of 40.6 hectares and is about 40 kilometres from Muar town (see Fig. 2). Next to Panchor flows the Muar River, one of several major rivers that pass through the states of Johor, Negeri Sembilan and Pahang.

\subsection{Research Design and Data Collection}

This study chose a qualitative approach to access the residents' perception of a river-based tourism development centre at Muar River in Panchor. Studies on a community's attitude towards tourism development by Gnanapala and Karunathilaka in 2016 showed that understanding community perception could provide decision-makers valuable insights into tourism development. Development depends mainly on the stakeholders' ability to identify risks, mitigate and adapt strategies, and assess the implications of the tourism development (Torres-Bagur, Palom \& Vila-Subiros, 2019). Hence, this study suggested using the open-ended format to get different responses (Darb, 2006). Data on the 562 Panchor residents were obtained from the Malaysian Department of Statistics (2011) while a purposive sampling technique allowed the study to determine a recommended sample size of at least 226 residents (Krejcie \& Morgan, 1970) as the target respondents of an open-ended survey. A total of 17 numerators helped administer the questionnaire survey, as well as handled residents' inquiries between March and April 2019. The study also interviewed with the Chief of Village Heads intended to enrich data analysis and to supplement information collected by the survey.

\subsection{Data Analysis Procedure}

The data gathered for the study came from the open-ended question and interview responses. Responses to open-ended questions were extracted from the questionnaire and the interview audio-records were transcribed, the contents were coded and processed for analysis. Following Braun and Clarke (2006), both the written responses of the open-ended questionnaire and the interview transcripts were analysed using the thematic analysis, which included data familiarisation, identification of recurring patterns and themes within the data, reviewing and defining themes as well as reporting themes. 


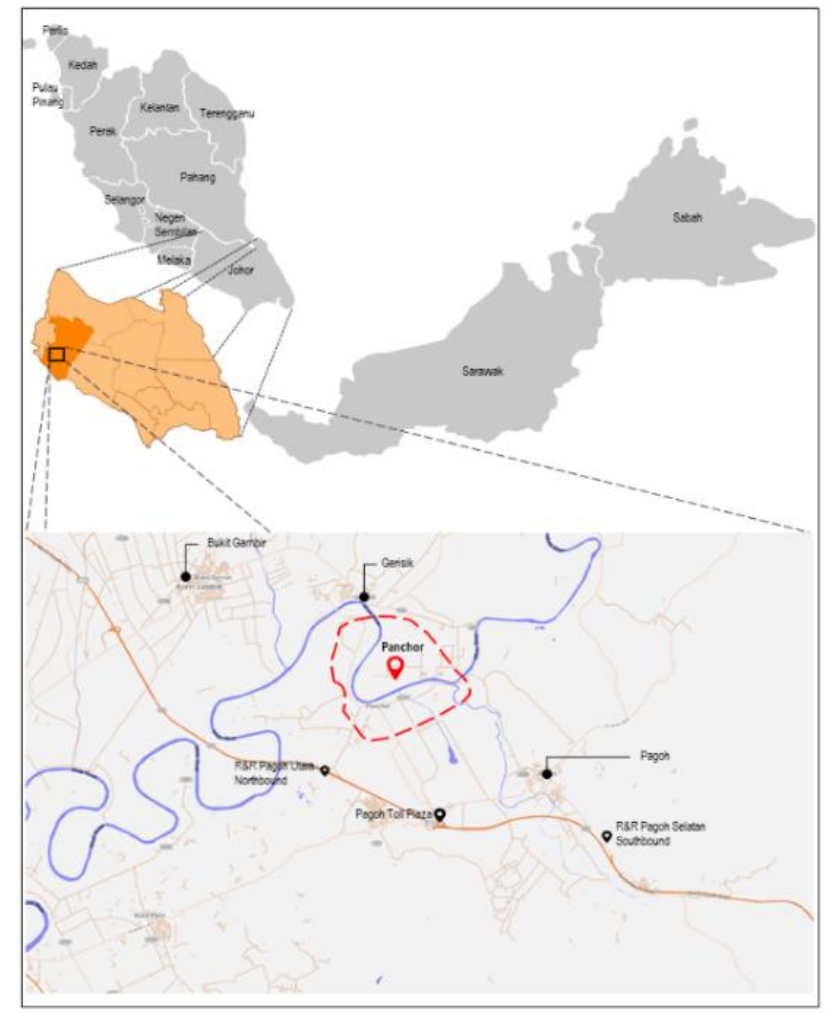

Fig. 2: Geographical location of Panchor Area Source: Hazizi (2020)

\subsection{Findings \& Discussion}

\subsection{Residents' Social Characteristics}

Of the 92 respondents of the survey, more than $71 \%$ of the Panchor villagers were males, while most $(92 \%)$ of them were Malays. The two largest groups in the sample were (23\%) Gen X (39-53 years old) and (41\%) Gen Y (24-38 years old). Over half of the respondents $(60 \%)$ had completed high school and some had tertiary education. As for the occupational background, $27 \%$ were working in the public sector and $25 \%$ were from the private sector. Almost $46 \%$ of the respondents had resided in Panchor over the past 20 years.

Following a conversation with Mr Khairunasir Md Zin, age 42 years old and lives in Muar, he is the Chief of Village Heads and he holds a Diploma in Business Management and a Diploma in Teaching (personal communication, April 9 2019). His main tasks are to administer the 'mukim' (a subdivision of a district) and to oversee the development, security, unity, religion and welfare of the people as well as assisting the District Officer on rural project proposals. The Chief of Village Heads who had been in office since 2014 was interviewed for approximately 80 minutes. The whole session was audio-recorded with his consent. The survey responses showed that the majority of the residents (95\%) showed positive support and involvement in the future development of a river-based tourist centre in the village. Only $5 \%$ of them were negative towards tourism development. The questionnaire was written responses and interview transcripts which were analyzed thematically produced three interconnected themes: (1) community attachment, (2) economic gains and (3) environmental attitude.

\subsection{Community Attachment}

From a socio-cultural perspective, community involvement is expected to have a significant impact on local support for tourism development, particularly in rural areas (Meimand, et al., 2017). The local community displayed an inclination to support tourism development if they perceive the benefits of river-based tourism. Based on the positive written responses by the respondents, it was divulged that the future river-based tourism development could enhance the unity within the local community such as in facilitating 'group gains' which refers to the benefits accrued by the community (Cropanzano \& Mitchell, 2005). The youth local community, within the age group of 18 to 38 , revealed that as they were still physically active, they would love to participate in some of the river-based activities. They also thought that being involved in such activities would create not only unity within their small community, but also individuals who are open-minded and have a strong sense of belonging towards their community (Jaafar, Rasoolimanesh, \& Ismail, 2015).

Some local communities according to Morales et al. (2018) also displayed a negative attitude towards tourism development and the factors that could influence such a manner and perception could be of a demographic, personal, or social. A small inclination from a personal aspect, however, revealed that the local community would only be willing to support the development of tourism if everyone in the community worked together. Another respondent confessed that the community would support tourism development only if proper procedures were implemented particularly concerning to the community's well-being and safety. Other written responses displayed a 
reluctance to be involved with river-based tourism due to old age. In contrast, some other older residents were content to be in their comfort zone and wanted only to attend to agricultural work on their fruit orchards.

\title{
4.3 Economic Gains
}

Residents who demonstrated great community attachment are more likely to make a crucial contribution to the development of sustainable tourism (Lee, 2013). The findings of this study unfolded respondents who displayed support towards tourism development in Panchor mainly because potential job opportunities for the locals could generate income and upgrade the local community's lifestyle. Table 1 below summarizes the written responses that are related to economic gains.

. Table 1. Related to Economic Gains

\author{
Respondents' Written Responses Summary \\ Promote Panchor River locally and internationally \\ Create a new job opportunity \\ Opportunity to open-up new businesses \\ Can increase the local economy and introduce Panchor to the outsider
}

The findings revealed significant positive support and involvement of the Panchor residents in the development of river-based tourism that could enhance the community's economic gains. At the interview with the Chief of Village Heads, he mentioned that "new industries will create job opportunities and draw locals back to Panchor. It also attracts outsiders to come here." Hence, new jobs opportunities would be able to attract the youth of the local community to work within their local areas thus decreasing the number of people migrating to cities to seek jobs. Following this, is the current development of the neighbouring regions of Pagoh Higher Education Hub, new housing areas, the future high-speed rail and other construction projects, all of which will contribute to revitalising Panchor's economic status. Furthermore, the respondents suggested that the nearby river as a natural resource has great potential in attracting local and foreign tourists. Some of the responses were, "As a local resident of Panchor, I think that it is time to revive Panchor's unique river which has not been explored to its potential." Another resident said, "It can attract more local and international tourists."

However, some responses showed the residents' resistance to river-based tourism due to their concerns on the social and environmental well-being of the community. In summary, river-based tourism can help to promote Panchor although sustainability measures for a rural area should be considered as a priority by all relevant bodies. The new tourism industry could make Panchor village town known to other visitors and also attract local as well as international stakeholders to open up new business avenues.

\subsection{Environmental Attitude}

Another significant finding on the attitude of the local community is the one related to the environment. Table 2 below shows a summary of some written responses extracted from the data related to the environmental attitude. Respondents had a positive perception and attitude towards river-based tourism development of their local area when matters on environmental awareness were focused on. However, the findings also disclosed resident awareness of how an imbalanced development of the local area could create pollution and could affect the cleanliness and natural beauty of the river. As described by Homsud (2017), a positive attitude is likely to occur when one sees the advantages of tourism in the local environment.

\section{Table 2. Related to Economic Gains}

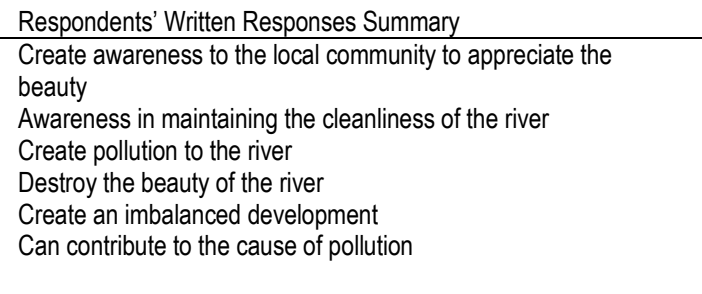

The interview conducted with the Chief of Village Heads displayed the local community's positive attitude towards the river-based tourism development of the village area. He also suggested that the current and future development of the neighbouring Panchor; the Education Hub of Pagoh, the High-Speed Rail, the Muar furniture Hub and the new housing areas could positively contribute to the improvement of public facilities and the creation of new job opportunities for the residents. However, all parties directly or indirectly involved in development activities must take responsibility for all the changes that could disrupt the preservation of natural resources or threaten the general well-being of the surrounding environment (Amir et al., 2015).

\subsection{Conclusion \& Recommendations}

The preliminary findings of this study indicate that a river-based tourism development of the Muar River in Panchor may just be the right initiative to stimulate the rather dull socio-economic condition of the residential area as well as foster sustainability. Being strategically 
located next to Muar River makes Panchor the natural host for a range of river-based activities for tourists such as boating, fishing, river cruising, river market and other local activities. These activities could invite more business opportunities that could potentially revive and promote Panchor into the next bustling, exciting and modern commercial hub of the region.

The study also reveals significant information on the host community's perception and potential involvement in a river-based tourism development plan. The results confirmed that the local community's expected social behaviour is an outcome of an exchange process as theorized by SET. As they begin to understand their new role as residents of a destination in the tourism industry, they become more aware and observant of the potential benefits and risks involved in their new social relationship with the tourists as well as the development project activities. The three themes that have emerged from this study; local attachment, economic gains and environmental attitude can be interpreted as the local community's positive expressions of their attitude, support and willingness to be involved as partners in developing Panchor's river-based tourism centre. Besides, the existing and upcoming development projects around Panchor area will give a fresh impetus to further business investments, in particular those related to tourism from interested stakeholders within and outside the state of Johor. A new vibrant economy also means a wider range of jobs to be taken up by the local youths who have left Panchor for work in bigger cities.

The findings of this study could be summarised as beneficial in three ways. Firstly, this study could be the main reference for the Ministry of Tourism, the Muar Municipal Council and the Johor State Tourism Board when promoting Muar River in Panchor as a tourist destination. Secondly, the tourism destination plan for Panchor could be the new stimulus package for the local community's economy and should be considered a state development project of high priority. Thirdly, Malaysian researchers of tourism could conduct a more in-depth sustainability study of Panchor as a river-based tourist destination including perhaps looking at how universities within the Pagoh Education Hub could play a more collaborative role in reviving and sustaining Panchor's economy.

This study is limited only to the participation of the younger residents of Panchor. It is therefore recommended that future studies invite the older residents, who are the main residents of the local community, to contribute to a more representative and realistic perspective of the town's future development into a tourism destination. Future studies could also validate their results by including the views of the neighbouring towns of Pagoh and Gerisik which could also experience some spill-over effects of the development of the surrounding rural area. Taken together, the study provides positive evidence that the host community is fully supportive of the riverbased tourism development of Panchor.

\section{Acknowledgements}

The authors would like to express special gratitude for the support received from 17 numerators of the Mags7 and M8-batch of the Tourism Department, Kulliyyah of Languages and Management who registered for the Transportation and Infrastructure in Travel Agency class in Semester 2, 2018/2019. The authors are indebted to Mr Haziq Danial Hazizi for the location and site plans of Panchor. Special thanks for the pictures shared by Mr Chua Teck Boon (Tourism Malaysia Association), Mr Mark Tee (Muar Dragon Boat Association), Datuk Gan Hong Su as well as Mr JackieNg, a local Muarian and an avid photographer.

\section{References}

Alonso, A. D., \& Liu, Y. (2013). Local community, volunteering and tourism development: The case of the Blackwood River Valley, Western Australia. Current Issues in Tourism, 16(1), 47-62.

Amir, A. F., Ghapar, A. A., Jamal, S. A., \& Ahmad, K. N. (2015). Sustainable tourism development: A study on community resilience for rural tourism in Malaysia. ProcediaSocial and Behavioral Sciences, 168(116-122).

Benjamin, N. (2018, December 10). Johor plans to develop more tourism products. Retrieved from https://www.thestar.com.my/metro/metronews/2018/12/10/johor-plansto-develop-more-tourism-products/

Braun, V., \& Clarke, V. (2006). Using thematic analysis in psychology. Qualitative Research in Psychology, 3(2), 77-101.

Chuang, S. T. (2010). Rural tourism: Perspectives from social exchange theory. Social Behavior and Personality, 38(10), 1313.

Cropanzano, R., \& Mitchell, M. (2005). Social exchange theory: An interdisciplinary review. Journal of Management, 31(6), 874900

Darb, A. J. (2006). Evaluating training courses: an exercise in social desirability? Journal of European Industrial Training, 30 (3), 227-239.

Department of Statistic Malaysia (2011). Taburan Penduduk Mengikut Kawasan Pihak Berkuasa Tempatan Dan Mukim. Retrieved from https://www.mycensus.gov.my/banci/www/admin/uploads/penerbitanpdf/13.pdf

Diedrich, A., \& García-Buades, E. (2009). Local perceptions of tourism as indicators of destination decline. Tourism Management, $30(4), 512-521$. http://dx.doi.org/10.1016/j.tourman.2008.10.009

Dorcheh, S. A., \& Mohamed, B. (2013). Local perception of tourism development: a conceptual framework for sustainable cultural tourism. J. Mgmt. \& Sustainability, 3 , 31.

Folgado-Fernández, J. A., Di-Clemente, E., Hernández-Mogollón, J. M., \& Campón-Cerro, A. M. (2019). Water Tourism: A New Strategy for the Sustainable Management of Water-Based Ecosystems and Landscapes in Extremadura (Spain). Land, 8(1), 2. 
Gnanapala, A. C. (2016). Community Perception on Tourism Development and Its Impacts: a Study on Passikudha, Sri Lanka. Tourism, Leisure and Global Change 3(2016), 164.

GongSu, G. (2020), Muar River River. Unpublished photo,

Hazizi, H.D. (2020). Geographical location of Panchor Area, Unpublished material, International Islamic University Malaysia.

Homsud, N. (2017). The Effect of Residents' Attitude toward Tourism to Pro-Tourism Behavior: A Case Study of Hua-Hin.

Jaafar, M., Rasoolimanesh, S., \& Ismail, S. (2015). Perceived sociocultural impacts of tourism and community participation: A case study of Langkawi Island. Tourism and Hospitality Research. doi:10.1177/1467358415610373

JackieNG (2020). Muar River. Unpublished photo.

Jennings, G. (2016). Water-Based Tourism, Sport, Leisure, and Recreation Experiences, 1-20.

Kariuki, P. N. (2013). Local residents' attitudes and perceptions towards tourism development: a study of lake Nakuru national park and its environs, Kenya (Doctoral dissertation, Moi University).

Krejcie, R. V., \& Morgan, D. W. (1970). Determining Sample Size for Research Activities. Educational and Psychological Measurement, 30(3), $607-610$.

Laws, E., \& Semone, P. (2009). The Mekong: Developing a new tourism region. River Tourism, 55-74.

Lee, T. H. (2013). Influence analysis of community resident support for sustainable tourism development. Tourism Management, 34, 37-46.

Md Zin, K. (personal communication, April 9, 2019).

Meimand, S. E., Khalifah, Z., Zavadskas, E. K., Mardani, A., Najafipour, A. A., \& Ahmad, U. N. U. (2017). Residents' Attitude toward Tourism Development: A Sociocultural Perspective. Sustainability, 9(1170), 1-29.

Morales, P. C., Agüera, F. O., López-Guzmán, T., \& Cuadra, S. M. (2018). Community Attachment and Support for Sustainable Tourism Development through the Attitudes of the Local Population: A Case Study in Puerto Plata, Dominican Republic. Mediterranean Journal of Social Sciences, 9(2), 173-184.

Paraskevaidis, P., \& Andriotis, K. (2017). Altruism in tourism: Social exchange theory vs altruistic surplus phenomenon in host volunteering. Annals of Tourism Research, 62, 26-37.

Rahman, N.H.A., Abas, S.A., Omar, S.R., \& Jamaludin, M.I. (2020). Exploring the river-based tourism product for Muar River: A tourism opportunity spectrum (TOS) approach. IOP Conference Series: Earth and Environmental Science, 447.

Rasoolimanesh, S. M., Jaafar, M., \& Ahmad, A. G. (2017). The effects of community factors on residents' perceptions toward World Heritage Site inscription and sustainable tourism development, 25(2), 198-216.

Rasoolimanesh, S. M., Jaafar, M., \& Kock, N. (2015). A Revised Framework of Social Exchange Theory to Investigate the Factors Influencing Residents' Perceptions. Tourism Management Perspectives, 16, 335-345.

Saad, M. (2019). Jetski at Muar River, Unpublished material, International Islamic University Malaysia.

Samah, B. A., Sulaiman, M., Shaffril, H. A. M., Hassan, M. S., Othman, M. S., Samah, A. A., \& Ramli, S. A. (2011). Relationship to the River: The case of the Muar River community. American Journal of Environmental Sciences, 7(4), 362-369.

Shah, M. F. (2018, January 13). Johor now a top tourism destination. Retrieved from https://www.thestar.com.my/news/nation/2018/01/13/johor-now-a-top-tourismdestination/

Tittenbrun, J. (2012). The Theory of Social Exchange of G.C. Homans

Tosun, C. (2006). Expected nature of community participation in tourism development, Tourism Management, 27 (3) 493-504

Trono, A. (2014). Cultural and religious routes: A new opportunity for regional development.

Torres-Bagur, M., Palom, A. R., \& Vila-Subirós, J. (2019). Perceptions of climate change and water availability in the Mediterranean tourist sector. International Journal of Climate Change Strategies and Management.

Ward, C., \& Berno, T. (2011). Beyond social exchange theory: Attitudes toward tourists. Annals of tourism research, 38(4), 1556-1569.

Zakaria, B.K. (2020, May 3. Pancuran darah asal nama Panchor, Retrieved from

https://www.bharian.com.my/hujung-minggu/kembara/2019/08/597255/pancuran-darah-asal-nama-panchor 